\title{
Polyculture of Giant Freshwater Prawn, Macrobrachium rosenbergii and Nilem Carp, Osteochilus hasselti Cultured in Recirculation System Using Biofiltration
}

\author{
Eri Setiadi ${ }^{1}$ and Imam Taufik ${ }^{1}$ \\ ${ }^{I}$ Research Institute for Freshwater Aquaculture and Fishery Extension, Bogor, West Java, Indonesia
}

\begin{abstract}
Giant Freshwater Prawn is one of the freshwater commodity which have an economy value where Nilem carp has also potentially to be cultured to produce fingerling size as a "baby fish". The purpose of this experiment is to determine the optimal survival, growth, FCR, and productivity of Giant Freshwater Prawn and Nilem carp cultured on polyculture system and also biomass productivity of bio filter (snail, water spinach, and Cabomba). The different stocking density of Nilem carp as a treatments were as followed: A) 25 fish $\mathrm{m}^{-3}$ B) 50 fish $\mathrm{m}^{-3}$, and C) 75 fish $\mathrm{m}^{-3}$. Density of Giant Freshwater Prawn was 20 individuals $\mathrm{m}^{-3}$ for all treatments. The result showed that the optimal of survival, growth (length and weight), productivity and FCR for Giant Freshwater Prawn was found

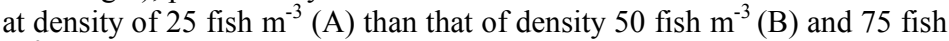
$\mathrm{m}^{-3}(\mathrm{C})(\mathrm{P}<0.05)$. The highest of biomass productivity of bio filter (snail, water spinach, and Cabomba) was found at density of $25 \mathrm{fish}^{-3}$ (A) than

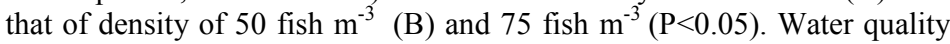
such as $\mathrm{DO}$, temperature and $\mathrm{pH}$ showed almost the same at all treatments.
\end{abstract}

\section{Introduction}

Giant Freshwater Prawn (Macrobrachium rosenbergii) is the one of commodity species that has an economy value. In Indonesia, Giant Freshwater Prawn has been initially cultured since 1970. Most of the culture technique on the earthen pond in Tasikmalaya and Ciamis areas are intensive system where rice field have been used for culture in Lamongan [1]. Thereafter, Giant Freshwater Prawn have been distribute to Bali and Borneo Islands [2]. Although Giant Freshwater Prawn have been cultured for 40 years but the productivity is low and unstable caused by traditional and semi-intensive system where stocking density is low (3-5 individuals $\mathrm{m}^{-3}$ ) which have resulted in low of survival (12.30-35.70\%) [2].

${ }^{1}$ Corresponding Author: erisetiadi@yahoo.com 
On the other hand, disease outbreak has also contributed to low productivity [3]. Some effort have been conducted to improve the production such as mono sex culture, polyculture, and using shelter in an extensive culture [1, 4]. Polyculture of Giant Freshwater Prawn to another fish species in Indonesia is clearly lacking. For instance, Polyculture Giant Freshwater Prawn with Gouramy [5, 4] and Red Tilapia [6]. However, the production is still not significant increase due to semi intensive system. Therefore, innovation to improve productivity via polyculture with intensive system is needed.

Nilem carp have a potential to be cultured, especially, to produce of fingerling 'baby fish". Market demand of this fish have increased in year by year Thus, Nilem carp has an economy value as a local fish [7]. Nilem carp is herbivore species because the main food of this species is detritus, phytoplankton and pheriphyton. Based on such condition, Nilem carp is called bio-cleaning agent [8].

Moreover, Nilem carp is easy to culture and resistance on environmental and disease [9]. Therefore, Nilem carp is suitable for culture with Giant Freshwater Prawn in a polyculture system.

Intensive culture is the most system that applied by fish farmer in Indonesia. This system believe that can increase the fish production. However, the negative impact of this system has a seriously problem even in the fish pond and environment. [10] reported that waste of the aquaculture activity have resulted in eutrophication and sedimentation in water bodies (e.g. lake and river) and salinization or acidification of soils. Richness nutrients from aquaculture activity had been increased in ammonia, nitrite, nitrate, and phosphate concentrations [11]. Ammonia and nitrite are toxic to aquatic organisms including fish [12]. To solve such problems, the recirculation system using bio filtration is known effective to reduce of waste come from aquaculture activity and water conserve. Recirculation system is efficient in term of water utility due to during the operation no need water exchange [13]. Microorganisms (bacteria and plankton), mollusk, and plants have been commonly used as a bio filtration to reduce of water pollutants from aquaculture effluents [14]. Mollusk have a function as filter feeder and very efficient in reducing of total suspended solid [15] where plants can absorb pollutants such as heavy metals, organic matters, nitrogen and phosphor [11].

The purpose of this experiment is to determine the optimal survival, growth, and biomass of Giant Freshwater Prawn and Nilem carp and also the biofiltration biomass such as water spinach (vegetable), snail, and Cabomba (ornamental aquatic plant).

\section{Materials and Methods}

The experiment was conducted from July to September 2016 at Research Station for Freshwater Aquaculture Environment Technology and Toxicology, Cibalagung, Bogor, Research Institute for Freshwater Aquaculture and Fishery Extension, Bogor, West Java, Indonesia.

Nine of concrete tanks with size of $4 \mathrm{~m}^{2}$ (2.3 length $\times 1.9$ wide $\times 1$ depth m) with completed by water pump and aeration were used for Giant Freshwater Prawn and Nilem carp culture. Giant Freshwater Prawn with $7.73 \pm 0.56 \mathrm{~cm}$ in total length and $4.31 \pm 0.98 \mathrm{~g}$ in body weight was used. Feeding rate was $5 \%$ a day biomass ${ }^{-1}$ and artificial diet with containing $35 \%$ protein was fed three times a day. Stocking density was 20 prawns for each tank. Newly hatched larvae (D1) of Nilem carp with $0.31 \pm 0.0316 \mathrm{~cm}$ in total length and $0.0012 \pm 0.00007 \mathrm{~g}$ in body weight were used. No feeding was fed during the experimental period. Culture period of this experiment was 60 days

Bio filtration box was made from wooden board with size of 2 length $\mathrm{x} 0.6$ wide $\mathrm{x} 0.4$ depth $\mathrm{m}$ for water spinach (Ipomoea aquatic) while wooden boards with size of 1 length $\mathrm{x}$ 0.6 wide x 0.4 depth $\mathrm{m}$ were used for snail (Pila ampulacea) and ornamental aquatic plant 
of Cabomba (Hydrilla sp). Initially of wet weight (biomass) of snail, water spinach, and Cabomba were $500 \mathrm{~g}, 540 \mathrm{~g}$, and $216 \mathrm{~g}$, respectively. Lime stone with $4-5 \mathrm{~cm}$ in diameter and gravel with $2-3 \mathrm{~cm}$ in diameter were used as a substrate for snail where limestone and pumice stone with $2-3 \mathrm{~cm}$ in diameter were used for water spinach. Gravel and sand were used for Cabomba. All boxes were covered using plastic sheet inside with completed by inlet and outlet. Net with size of 0.8 length $\times 0.5$ wide $\times 0.4$ depth $\mathrm{m}$ was placed inside the box then the snail were introduce into the net which completed by zippers to avoid of escape.

All concrete tank were set up in recirculation system. Water from concrete tank was transferred using water pump into the snail box then the water through into the water spinach box and then into the Cabomba box. Finally, water flow back through the concrete tank. The layout of recirculation system and implementation of the system in the field were shown in Figure 1.

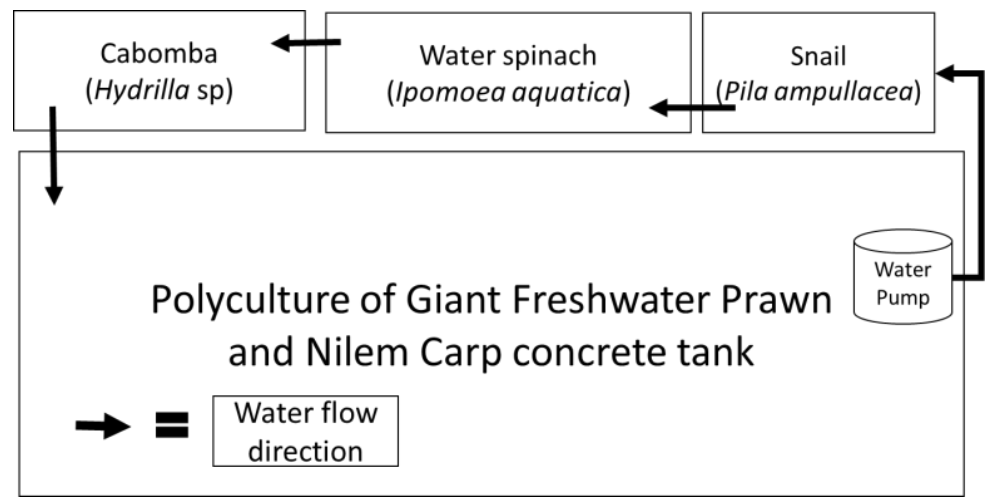

a

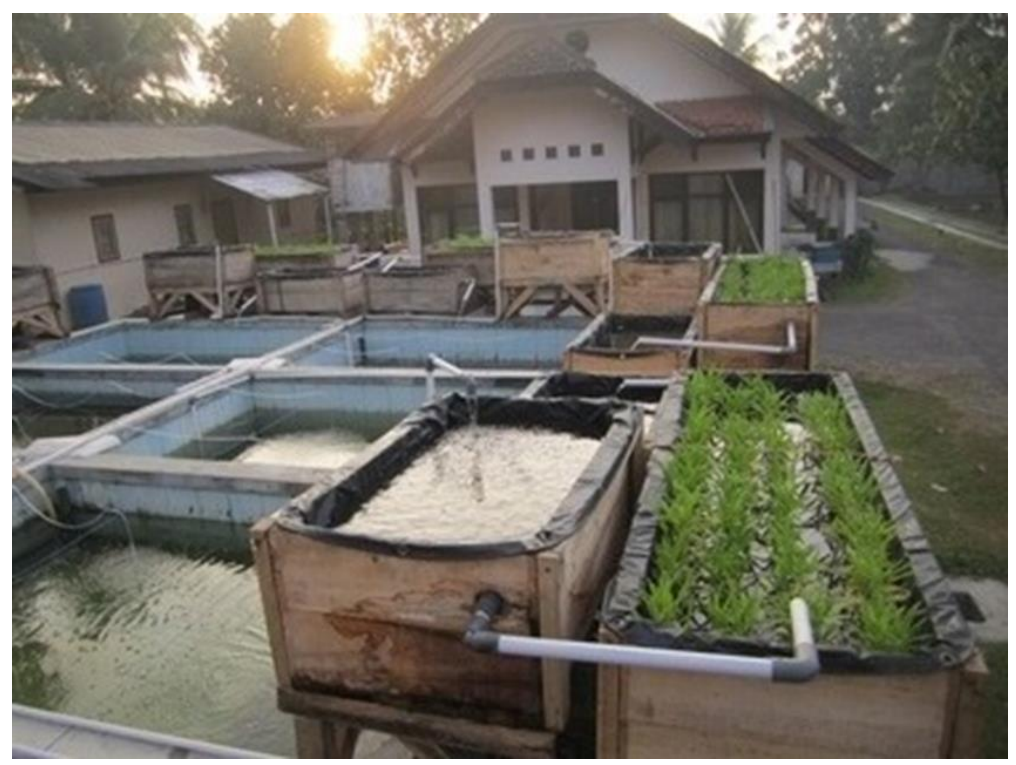

$\mathrm{b}$

Fig 1. Recirculation system of polyculture Giant Freshwater Prawn (Macrobrachium rosenbergii) and Nilem Carp (Ossteochilus hasselti) using biofiltration. a) The layout of recirculation system and b) Implementation of the recirculation system in the field. 
Different stocking density of Nilem carp as a treatment were as followed A) 25 fish m m, $^{-2}$ B) 50 fish $\mathrm{m}^{-2}$, and C) 75 fish $\mathrm{m}^{-2}$. Parameters observed were survival, growth, and biomass. Data of the total length and weight, 35 Giant Freshwater Prawn were sampled for initial and final weight while 10 newly hatched larvae and 10 fish of Nilem carp. The survival and biomass data were obtained from the population and total weight of population both of Giant freshwater Prawn and Nilem Carp at the times of harvested. All data were analyzed using formula [16] were as followed:

- Weight gain $(\mathrm{g})$ :

Weight gain $=$ Mean final weight - Mean initial weight

- Percent weight gain (\%):

$\%$ weight gain $=\frac{\text { Mean final weight }- \text { mean initial weight }}{\text { mean initial weight }} \times 100$

- $\quad$ Survival rate (\%):

Survival Rate $(\%)=\frac{\text { No.of total live prawn }}{\text { Total no.of prawn stocked }} \times 100$

- $\quad$ FCR (Feed Conversion Ratio):

$$
F C R=\frac{\text { Total feed consumed }(\mathrm{kg})}{\text { Total yield }(\mathrm{kg})}
$$

- Biomass/net Production:

The net production of prawn $(\mathrm{Kg} /$ decimal) was calculated by the following formula:

Biomass $(\mathrm{kg} /$ decimal $)=\frac{\text { survival rate } x \text { stocking density } x \text { weight gain }(\mathrm{gm})}{100 \times 1000}$

All data of survival, growth (length and weight), and biomass were statistically analyzed using completed randomized design with three treatments and three replicates. If there was significant different among the treatments, Tukey's test was performed. Water quality parameters such as temperature, $\mathrm{pH}$, and dissolved oxygen (DO) were analyzed using descriptive.

\section{Results and Discussion}

Result of polyculture of Giant Freshwater Prawn and Nilem carp on survival, growth (length and weight), and biomass are shown in Figure 2. Over all data showed that the survival, total length, weight, and biomass both of Gian Freshwater Prawn and Nilem Carp decreased led to increasing of stocking density of Nilem carp (Fig. 2). The highest of survival, total length, weight, and biomass whether Giant Freshwater Prawn or Nilem carp were found at density of 25 fish $\mathrm{m}^{-2}$ (A), followed by density of 50 fish $\mathrm{m}^{-2}(\mathrm{~B})$, and 75 fish $\mathrm{m}^{-2}(\mathrm{C})(\mathrm{P}<0.05)$. This indicated that different stocking density of Nilem carp affect the survival, growth (total length and weight), and biomass where at high stocking density have resulted in low of survival, growth, and biomass. At high stoking density in polyculture have resulted more competitive in term of food, locomotion, and space. 

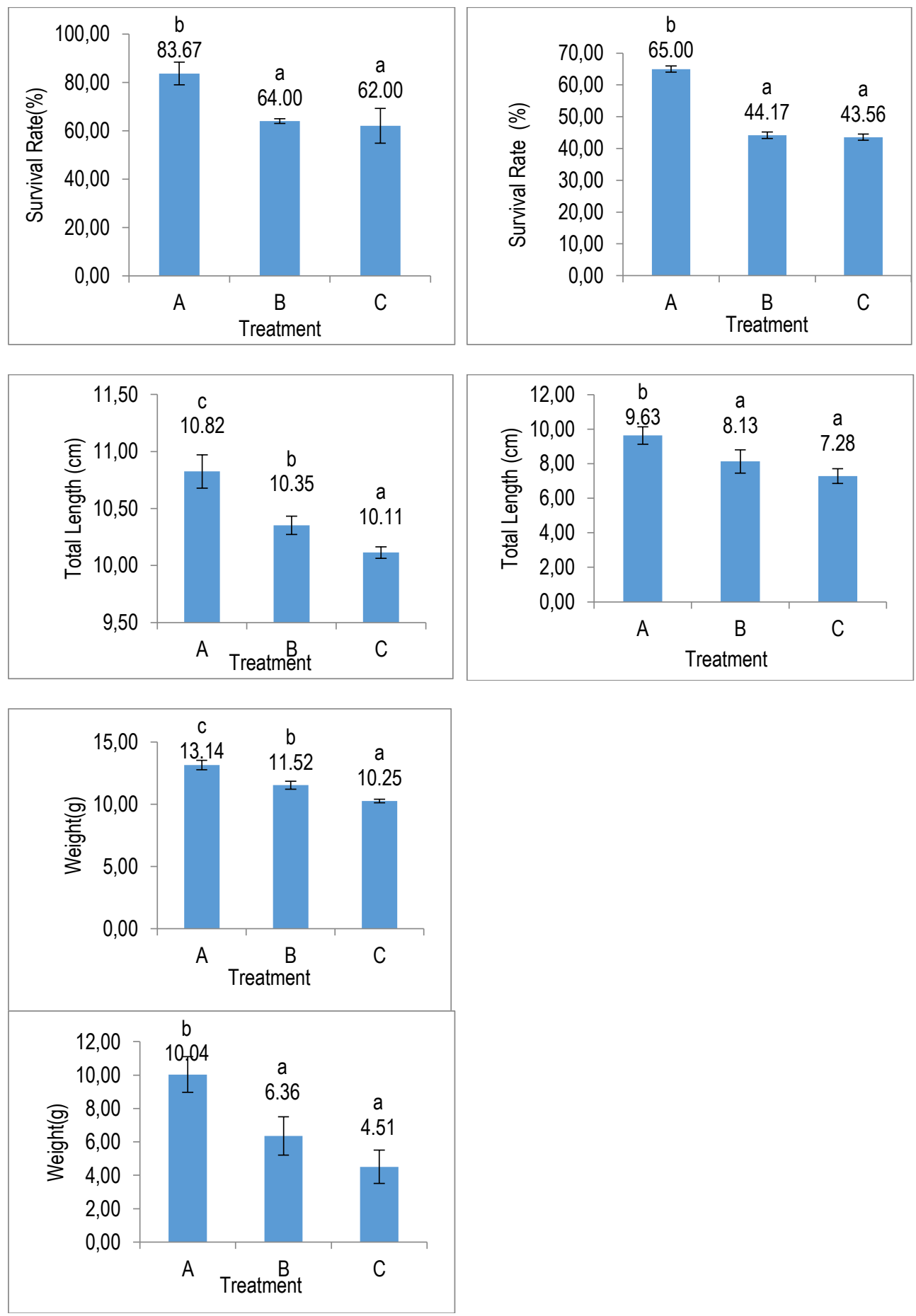


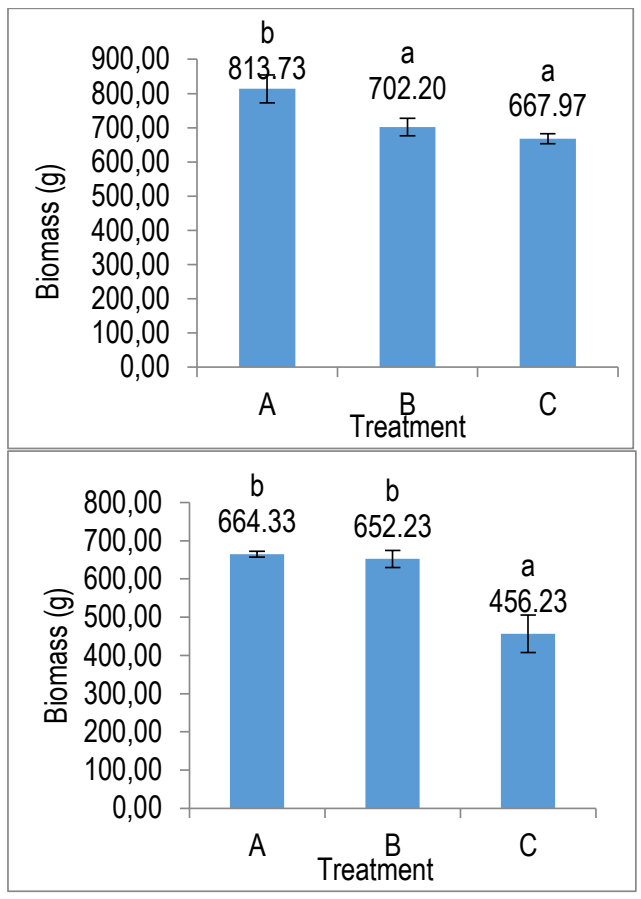

Fig 2. The survival, total length, weight, and biomass of Giant Freshwater Prawn (Macrobrachium rosenbergii) and Nilem carp (Ostechilus hasselti) cultured in polyculture system

[17] stated that inappropriate ratio or number between one species to the other species in polyculture affect the survival, growth, and biomass which is caused by high competitive food sources, space, and locomotion. The present experiment, although Giant freshwater Prawn have feeding habit and niches different from Nilem carp but at high stocking density of Nilem carp shows clearly that food and space competitive occurs. High stocking density is also impact on physiological, mainly, stress that affect fish growth and survival [18]. The different stage and fish species selection for introducing into the pond with polyculture system is very important in order to obtain optimal production [19]. [4] reported that high stoking density of Gouramy is followed by high mortality and low of biomass.

Feeding conversion ratio (FCR) of Giant Freshwater Prawn and Nilem Carp cultured on polyculture system is shown in Figure 3. 


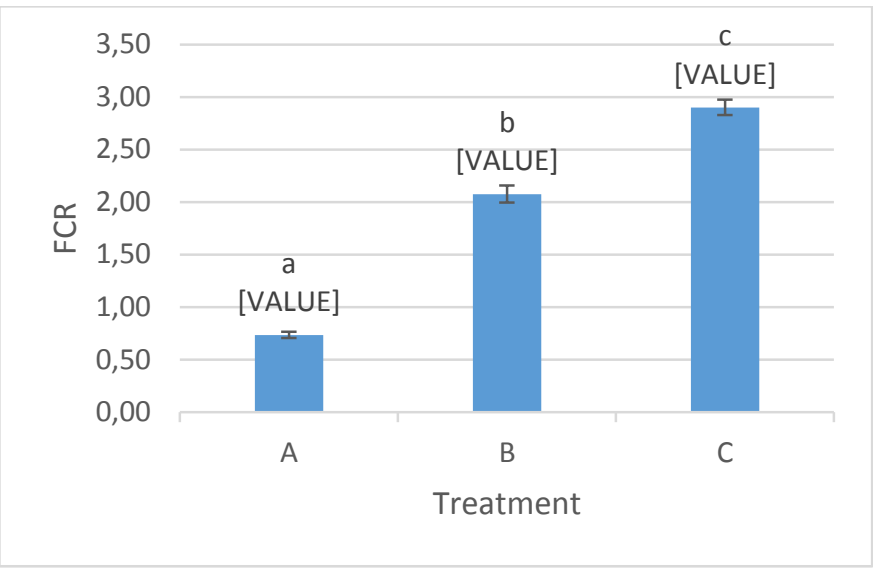

Fig 3. Feeding conversion ratio of Polyculture of Giant Freshwater Prawn, Macrobtachium rosenbergii and Nilem Carp, Osteochilus hasselti

Feeding conversion ratio of polyculture of Giant Freshwater Prawn and Nilem carp (Fig. 3) showed increase with increasing in stocking density of Nilem carp. The highest of FCR $(2.90 \pm 0.07 \%)$ was found at density of 75 fish $\mathrm{m}^{-2}(\mathrm{C})$, followed by density of 50

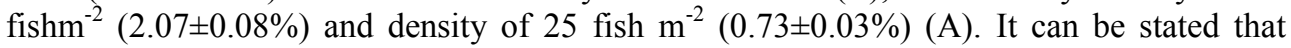
stocking density affect the feeding conversion ratio where the high stocking density would be led to increase FCR. Similar result had been reported that increasing on stocking density of Gouramy was led to increase in FCR [4]. The present experiment can be explained that food source such as natural food that exist in the pond insufficient for supplying Nilem carp. Thus, artificial diet that mainly feed to Giant Freshwater Prawn only is also taken by Nilem carp. [20] reported that inadequate the number of stocking density have influenced on food supply where the main food become used for consuming all fish.

Biomass productivity of bio filtration such as snail, water spinach, and cabomba on polyculture of Giant Freshwater Prawn and Nilem carp is shown in Figure 4.

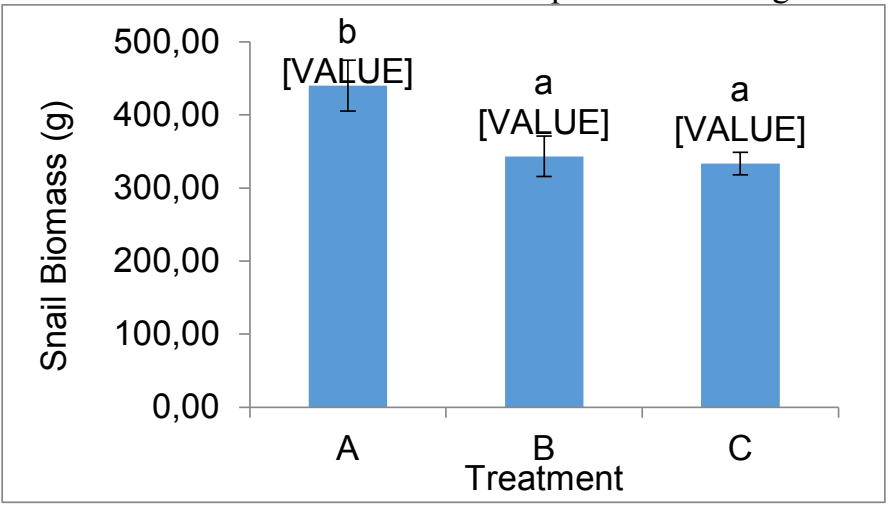



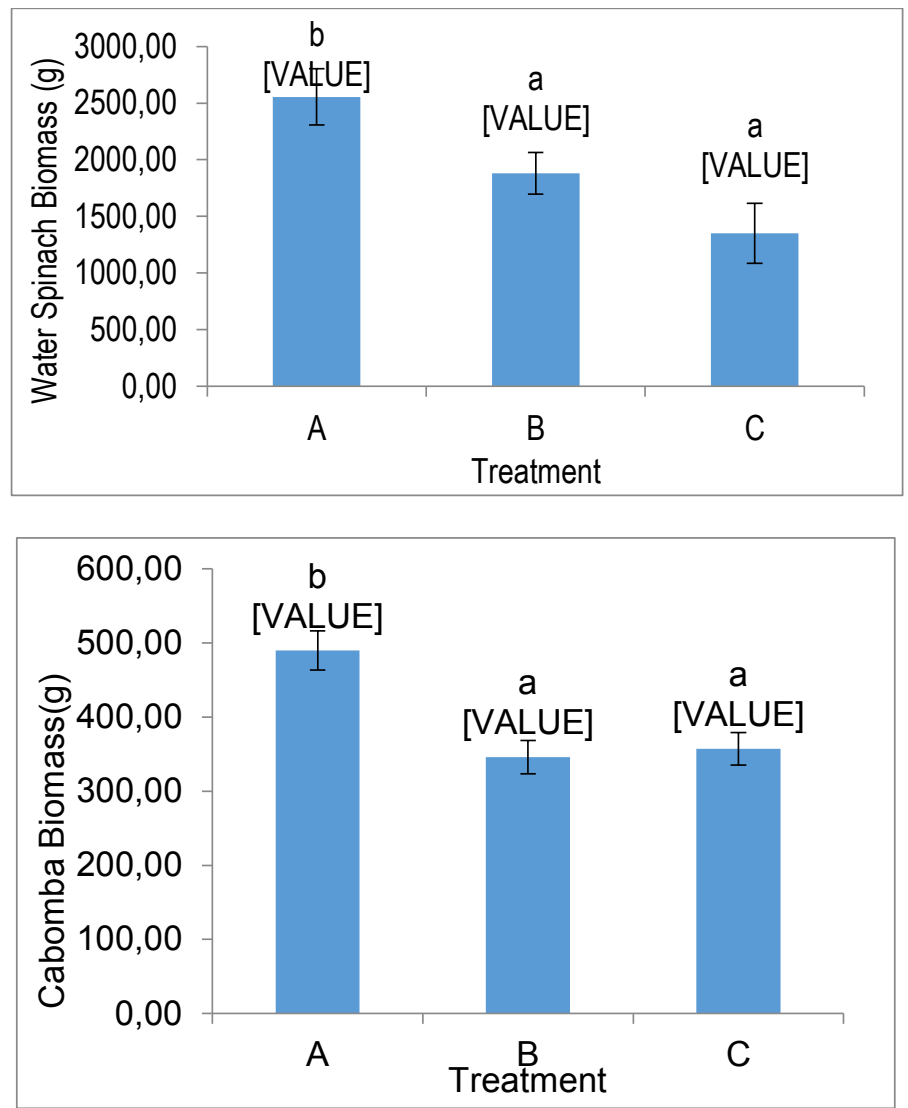

Fig 4. Biomass biofiltration of snail (Pila ampulacea), water spinach (Ipomoea aquatic), and cabomba (Hydrilla $\mathrm{sp}$ )

The highest of biomass productivity of bio filtration such as snail, water spinach, and cabomba (Fig. 4) was encountered at density of fish $25 \mathrm{~m}-2$ (A), followed by density 50 fish $\mathrm{m}-2(\mathrm{~B})$, and 75 fish $\mathrm{m}-2(\mathrm{C})(\mathrm{P}<0.05)$. This suggested that biomass productivity of bio filtration might be related to the waste product that obtained by aquaculture activity. Waste aquaculture increase with increasing the biomass of fish and time period of culture [11]. The present experiment shows that the highest of Giant freshwater Prawn and Nilem carp biomass was found at density of $25 \mathrm{fish}^{-2}$. Therefore, high waste of aquaculture have also high containing nutrients that consume by snail and to be absorbed by plants. [15] reported that total suspended solid concentration have correlated to mussel grows. High nutrients concentration in the pond water column that derived from feces, urine, and uneaten food. These nutrients containing nitrogen and phosphor elements that important for plant growth $[21,22]$.

Water quality such as temperature, $\mathrm{pH}$, and dissolved oxygen (DO) during culture period of Giant Freshwater Prawn and Nilem Carp is presented at Table 1. 
Table 1. Water quality

\begin{tabular}{|c|c|c|c|}
\hline \multirow{2}{*}{ Treatments } & \multicolumn{3}{|c|}{ Parameters } \\
\cline { 2 - 4 } & DO $(\mathrm{mg} \mathrm{L})$ & Temperature $\left({ }^{\circ} \mathrm{C}\right)$ & $\mathrm{pH}$ \\
\hline $\mathrm{A}$ & $3.3-3.6$ & $27.5-27.8$ & $6.7-7.1$ \\
\hline $\mathrm{B}$ & $3.1-3.9$ & $27.0-27.6$ & $6.3-6.9$ \\
\hline $\mathrm{C}$ & $3.2-3.8$ & $27.2-28.0$ & $6.4-6.8$ \\
\hline Optimal Range & $\geq 3^{23)}$ & $26-30^{23}$ & $6-9^{23}$ \\
\hline
\end{tabular}

Remaks: ${ }^{23)}$ government regulation No. 82 (2001)

All water quality parameters such as dissolved oxygen (DO), temperature, and $\mathrm{pH}$ were within the optimal range both of Giant Freshwater Prawn or Nilem Carp culture. The present experiment imply that Polyculture of Ginat Freshwater Prawn and Nilem Carp in the recirculation system using biofiltration can keep water quality..

\section{Conclusions}

The optimal of growth, survival, and biomass productivity both of giant freshwater prawn and nilem carp is the density of 25 fish $\mathrm{m}^{-3}$. The higher of biomass production of bio filter (snail, water spinach, and cabomba) is encountered at density of 25 fish m-3. Water quality parameters (temperature, $\mathrm{pH}$, and $\mathrm{DO}$ ) is within in the optimal range for all treatments.

\section{References}

1. F. Ali. Growth of Indonesian Giant Freshwater Prawn (Macrobrachium rensenbergii) in a closed aquaculture system with artificial shelter. LIMNOTEK, XIV(1): 29-36 (2007)

2. L. E. Hadie, W. Hadie, Imron, I. Khasani, N. Listyanto. Strategi pengembangan budidaya udang galah GIMacro. Forum Inovasi Teknologi Akuakultur. p.67-77 (2010)

3. I. Khasani. Upaya peningkatan produktivitas dalam usaha pembesaran udang galah (Macrobrachium rosenbergii De Man). Media Akuakulture, 3 (1): 25-30 (2008)

4. D. Rohmana, C.H. Adi, A. J. Pamungkas, S. Roselia. Polikultur udang galah (Macrobrachium rosenbegii) dan gurami (Osphronemus goramy) sistem esktensif. Seminar Nasional Hari Pangan Sedunia XXVII. p. 222-226 (2007)

5. A. Yustiati, T. Herawati, W. Lili, A. Nurhayati, Rosidah, I. B. B. Suryadi. Budidaya Polikultur Ikan Gurame (Osphronemus gouramy) dengan Udang Galah (Macrobrachium rosenbergii). Jurnal Pengabdian kepada Masyarakat. 2(1):44-46 (2018).

6. DKPDIY (Dinas Kelautan dan Perikanan Daerah Istimewa Yogjakarta). Polikultur udang galah dan nila merah. (2016)

7. D. T. Mulyasari, Soelistyowati, A. H. Kristanto, and I. I. Kusmini. Karakteristik Genetik enam populasi ikan Nilem (Osteochilus hasselti) di Jawa Barat. Jurnal Riset Akuakulture, 5(2): 175-182 (2010)

8. F. Cholik, A. G. Jagatraya, R. P. Poernomo, and A. Jauzi. Akuakultur: Tumpuan Harapan Masa Depan Bangsa. Masyarakat Perikanan Nusantara dan Taman Akuarium Air Tawar TMII, Jakarta p. 415. (2005)

9. Y. Hermawan, Rosmawati, and Mulyana. Gorwth and Survival Rate of Nilem (Osteochillus hasselti) with Different Feeding Rate. Jurnal Mina Sains, 1(1): 19-23 (2015) 
10. M. Martinez-Porchas and L. R. Martinez-Cordova. World Aquaculture: Environmental Impacts and troubleshooting alternatives. The Scientific World Journal (2012)

11. E. Setiadi, \& L. Setijaningsih. Improving water quality and productivity of tilapia Oreochromis niloticus using constructed wetland. Indonesian Aquaculture Journal, 6: 107-122. (2011)

12. O. F. Joel and C. A Amajuoyi. Determintation of Concentration of Ammonia that could have Lethal Effect on Fish Pond. Asian Research Publishing Network Journal of Engineering and Applied Sciences, 5 (2): 1-5 (2010)

13. FAO. A Guide to Recirculation Aquaculture an Introduction to Environmentally friendly and Highly Productive Closed Fish Farming System. Edited by Jacob Bregenballe. EUROFISH International Organisation. pp 100. (2015)

14. A. E. Turcios and J. Papenbrock. Sustainable Treatment of Aquacuaculture EffluentsWhat Can We Learn from the Past for the Future. Sustainability, 6: 836-856 (2014)

15. D. Puspaningsih and E. Setiadi. Potensi kijing local (Pilsbryoconcha exillis) sebagai biofilter untuk mengurangi TSS pada budidaya ikan nila. Prosiding Forum Inovasi Teknologi Akuakultur. Pusat Penelitian dan Pengembangan Perikanan, Badan Penelitian dan Pengembangan Kelautan dan Perikanan, Jakarta. (2013)

16. P. Paul, A. Rahman, M. Hossain, S. Islam, S. Mondal, and M. Haq. Effect of Stocking Density on the Growth and Production of Freshwater Prawn (Macrobrachium rosenbergii). International Journal of Fisheries and Aquaculture Sciences. 6 (1): 77-86 (2016)

17. I. Taufik, Sutrisno, and E. Setiadi. The Optimal Ratio of Nle Tilapia (Oreochromis nilotica) and Common Carp (Cyprinus carpio) for Improving on Deep Water Pond. Indonesian Aquaculture Journal, 8 (1): (2013)

18. I. Lupatsch, G. A. Santos, J. W. Schrama, and A. J. Verreth. Effect of stocking density and feeding level on energy expenditure and stress responsive in European sea bass Dicentrarchus labrax. Aquaculture, 298:245-250 (2010)

19. B. C. Mohapatra, S. K. Singh, B. Sarkar, D. Majhi, and N. Sarangi. Observation of Carp poluculture with Giant Freshwater Prawn in Solar Heated Fish Pond. Journal of Fisheries and Aquatic Sciense. 2(2):149-155 (2007).

20. M. J. Alam, D. A. Jahan, W. A. Pramanikand, and M. E. Hoq. Poly culture of freshwater prawn, Macrobrachium rosenbergii, de Man with carps: effects of prawn stocking density. Bangladesh]. Fish. Res., 5(2): 135-144 (2001)

21. Nuryadi and E. Setiadi. Produksi benih ikan lele (Clarias sp.) menggunakan sistem firoremdiasi. Prosiding Forum Inovasi Teknologi Akuakulture. Pusat Penelitian dan Pengembangan Perikanan, Badan Penelitian dan Pengembangan Kelautan Perikanan, Jakarta. (2012)

22. E. Setiadi. Kleinschlige aquaponics voor voedselzekerheid in Indonesia. Aquaculture, 3:34-37. (2017).

23. Government Regulation. Government Regulation of Republic of Indonesia Number 82. Water quality management and Water pollution protection. Jakarta (ID): Sekretariat Negara. 46. (2001). 